\section{ekf}

WYSOKÁ ŚKOLA BÁŇSKA AERZITAOSTRAVA EKONOMICKÁ FAKULTA

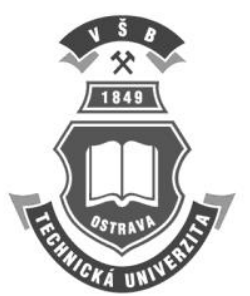

\title{
The performance of high-tech companies: The evidence from the Visegrad Group
}

\author{
Anna AFONINA ${ }^{\mathrm{a}^{*}}$, Vladimír CHALUPSKÝ \\ ${ }^{a}$ Department of Business and Management, Faculty of Business and Management, Brno University of Technology, Kolejni 2 \\ 906/4, 61200 Brno Czech Republic.
}

\begin{abstract}
The purpose of this paper is to analyse the financial performance of large high-tech companies (both product- and service-oriented) in the Visegrad Four (V4) countries. We concentrate on the five-year period from 2007 to 2011. As the performance indicators, the most frequent financial measures - liquidity, profitability and solvency ratios are used. We use two-dimensional classification to analyse the financial situation of large high-tech companies among the countries in the Visegrad Group. The research sample includes 139 Czech, 68 Hungarian, 270 Polish and 37 Slovak large high-tech companies. The results from this study indicate that the profitability, liquidity and solvency ratios increased in large manufacturing high-tech companies within the investigated period in the Czech Republic and Slovakia, while in Poland and Hungary the situation in the manufacturing sector was exactly the opposite. In terms of the service high-tech sector in the Visegrad countries, the ratios are volatile with a decreasing tendency. The results also indicate that the high-tech sector consists of companies with high liquidity, rather than companies with strong profits. Finally, correlation and regression analyses are conducted to examine the nature and extent of the relationship between profitability and liquidity.
\end{abstract}

\section{Keywords}

Financial performance, high-tech companies, Visegrad Four.

JEL Classification: C12, C80, R10, G00, O57

\footnotetext{
*afonina@fbm.vutbr.cz (corresponding author)
} 


\title{
The performance of high-tech companies: The evidence from the Visegrad Group
}

\author{
Anna AFONINA, Vladimír CHALUPSKÝ
}

\section{Introduction}

The development of the high-tech sector is one of the major strategies to achieve economic prosperity in every country. In order to stay competitive in the global market, companies are raising their market share through innovations, creating new products, services and capabilities. The global economic crisis of 2008-2009 had a significant impact on this sector. At that time, European countries were losing ground in global sales. Based on the Economist Intelligence Unit (EIU) data, the global industrial production has increased only by $0.1 \%$ since the crisis (EIU, 2013). Khoury and Hervé (2011) noted that high-tech companies are entering a period of re-evaluation. In other words, this sector of the economy needs to change its priorities and rearrange its resources to remain competitive in the global market. High-tech companies are associated with innovation and high-value-added production. It is well established in the literature that the high-tech sector is becoming a powerful force in domestic and global environments. According to the Czech Statistical Office, the hightech sector is defined as a set of economic activities that largely invest in research and development and their products reflect the latest research and development outcomes and innovations (Český statistický úr̆ad). Biming (2011) selected the next characteristics of high-tech companies: (1) have strong uncertainty, which is reflected in the development of leading technologies, fast replacement of technology and short-term product life cycle; (2) have a high value of human resources, in other words have a high level of personal organization; and last (3) have a high correlation between the values of intangible assets, such as proprietary technology, strength of innovation, quality of human resources and others.

In this paper we analyse the financial performance of the large high-tech companies in the Visegrad Group, which consists of four European countries: the Czech Republic, Slovakia, Poland and Hungary. These countries are known in the EU market as countries with low material costs and low labour costs. Timmer et al. (2013) mentioned in his study that the economies of the Czech Republic and Slovakia specialize mainly in machinery, Hungary and Slovakia specialize in electronics and all the V4 countries focus on transport equipment. In comparison with Poland, which has a big internal market, the Czech Republic and Slovakia are more dependent on the foreign market. This means that these countries are more oriented towards export and have a strong dependence on foreign inputs (Grodzicki, 2014).

In the conditions of the global economic crisis, the investments in the Visegrad region fell. For example, the investment rate in the Czech Republic decreased slightly after the crisis, while in Slovakia this rate increased. Furthermore, Slovakia reported quick GDP growth after the crisis (Nečadova and Scholleova, 2013). This could have been caused by the euro adoption of the Slovak economy. One of the most direct benefits of euro adoption is the elimination of transaction costs on trades in euros. In addition, the euro adoption in the Slovak economy facilitated the inflow of investment (Šuster, 2006). According to the Bloomberg Innovation Index report in 2013, the countries from the Visegrad Group take places from 23 to 34 on the list. The Czech Republic scores better than the other countries in the V4 and is in the twenty-third place among the most innovative countries.

The role of the high-tech sector is significant for all four economies. This sector produces approximately from $30 \%$ to almost half of the domestic product (Grodzicki, 2014). Thus, the analysis of the high-tech industry requires greater attention among practitioners and researchers. Numerous studies have examined the research and development activity and organizational performance of high-tech companies. The most frequently used methods for evaluating a company's performance are analyses of the key financial ratios, namely profitability, liquidity and solvency. Profitability evaluates a company's ability to generate earnings relative to sales, assets or equity. This indicator can be measured by different ratios, such as return on assets (ROA), return on equity (ROE), return on sales (ROS), net income, profit margin and return on investment (Carton and Hofer, 2006). All these measures allow researchers and executives to compare companies in the same industry and to assess the financial stability of a 
company. For example, Robinson's study (1995) showed that the most traditional financial performance measures are return on assets, return on equity, return on investment (ROI) and return on sales (ROS) (Carton and Hofer, 2006). The next most commonly used ratio is liquidity, which represents a company's ability to pay its liabilities in time. This ratio also allows researchers to indicate financial stability.

Therefore, based on the literature review, we select the following ratios - return on equity, return on assets, profit margin, current ratio and solvency ratio - to assess the financial stability and financial performance of large high-tech companies in the Visegrad Group. The objectives of this study are:

- to explore the profitability, liquidity and solvency ratios within the manufacturing and service sectors in the Visegrad Group;

- to assess the economic and financial situation of the large high-tech companies among the countries in the V4;

- to examine the relationship between profitability and liquidity.

The paper includes several parts. Section 2 describes the research methodology. In section 3 the results are demonstrated and discussed. Section 4 presents the relationship between liquidity and profitability, while section 5 concludes.

\section{Research methods}

Firstly, for the purpose of this study, the high-tech industry is defined as a set of economic activities that widely use advanced technology for their production (Necadova and Scholleová, 2012). Secondly, in order to be included in the sample, the companies should meet the following criteria:

- Country: the Czech Republic, Hungary, Slovakia, Poland

- Category of companies by size: large and very large (more than 250 employees)

- NACE revision 2 codes - three-digit-level and two-digit-level classification

- Years with available accounts: 2007-2011

According to the Statistical Classification of Economic Activities in the European Community, NACE (Nomenclature generale des Activites economiques dans les Communautes Europeenes), the high-tech sector is divided into two main groups:

- High-tech manufacturing industries

- High-tech service industries (KISs knowledge-intensive services) (NACE, 2008)

Based on the NACE revision 2 codes' threedigit-level classification, the high-tech manufacturing industries are grouped into the following catego- ries: manufacturers of basic pharmaceutical products and pharmaceutical preparations; manufacturers of computer, electronic and optical products; and manufacturers of air and spacecraft and related machinery (NACE, 2008). The aggregation of the service sector is based on the NACE two-digit level. Therefore, following a similar approach, high-tech knowledge-intensive services (KISs) are divided into several categories: motion pictures, video and television programme production, sound recording and music publishing activities, programming and broad casting activities, telecommunications, computer programming, consultancy and related activities, information service activities and scientific research and development.

The same sampling criteria were used for all the countries. After screening, the research sample consisted of 139 Czech, 68 Hungarian, 270 Polish and 37 Slovak large high-tech companies.

In order to assess the financial performance among large companies in the Visegrad Group, we used the following ratios:

Table 1 Measures used in the research

\begin{tabular}{|l|l|}
\hline Ratios & \multicolumn{1}{|c|}{ Formula } \\
\hline Return on equity & $\begin{array}{l}\text { ROE }(\%)=(\text { Profit and Loss before } \\
\text { tax/Shareholder funds) } \cdot 100\end{array}$ \\
\hline Return on assets & $\begin{array}{l}\text { ROA }(\%)=(\text { Profit and Loss before } \\
\text { tax /Total assets) } \cdot 100\end{array}$ \\
\hline Profit margin & $\begin{array}{l}\text { Profit margin }(\%)=(\text { Profit and Loss } \\
\text { before tax /Sales) } \cdot 100\end{array}$ \\
\hline Current ratio & CR = current assets/current liabilities \\
\hline $\begin{array}{l}\text { Solvency ratio } \\
(\%)\end{array}$ & $\begin{array}{l}\mathrm{SR}=(\text { shareholders funds/total assets }) \\
\cdot 100\end{array}$ \\
\hline Liquidity ratio & $\begin{array}{l}\mathrm{LR}=(\text { Current assets }- \text { stock)/ current } \\
\text { liabilities }\end{array}$ \\
\hline
\end{tabular}

The data used for the analysis were extracted from the Amadeus Bureau Van Dijk database for five years from 2007 to 2011. It is necessary to mention that the study includes one year (2007) before the crisis, two years (2008 and 2009) of economic crisis and one year (2011) after the crisis. The SPSS software was used for the analysis of the different variables in this paper. We used the descriptive statistic method to compare the profitability, liquidity and solvency of high-tech companies in the selected countries. We also utilized the Pearson correlation analysis to measure the degree of association between the selected profitability and liquidity ratios. Subsequently, the linear regression method was employed.

\section{Research findings and discussion}

The research findings and discussion section consists of two parts. The first part describes the per- 
formance of high-tech companies in the Visegrad Group. The second part presents the twodimensional classification of the high-tech sector.

\subsection{The performance of high-tech companies}

In order to analyse the performance of large manufacturing and service companies in the Visegrad Group, we selected the ratios mentioned above in table 1. Figures 1-5 (Appendix A) show the general dynamics of the return on equity, return on assets, profit margin, current ratio and solvency ratio of manufacturing high-tech companies in the Czech Republic, Hungary, Poland and Slovakia within the investigated period. These figures clearly indicate that only in two countries, the Czech Republic and Slovakia, were all five indicators in large manufacturing companies volatile with a tendency to increase within the period from 2007 to 2011 (figure 1-5, Appendix A). As for Poland and Hungary, the situation in the manufacturing sector was exactly the opposite. A sudden drop in the ROE and profit margin is identified in Hungary (figures 1 and 3, Appendix A). We can also see from figure 5 that the average solvency ratio in all the countries was over $20 \%$. This means that the high-tech manufacturing industry can be considered as financially healthy.

Figures 6, 7 and 8 (Appendix A) reflect the dynamics of the profitability ratios specifically as the return on equity, return on assets and profit margin of the high-tech service companies. Figures 9 and 10 (Appendix A) show the general dynamics of the current ratio and solvency ratio of service high-tech companies in the Visegrad Group countries. As we can see, in Hungary and the Czech Republic, the profitability ratios were declining. Additionally, in Slovakia, the profitability ratios show a sudden significant drop (figures 6-8, Appendix A). As for Poland, the profitability ratios show a similar tendency to decrease during the investigated period. These figures clearly indicate that all the profitability ratios mentioned above were volatile with a tendency to decrease within the investigated period in all the Visegrad Group countries. In terms of the high-tech service industry, the downturn reduced the profitability ratios in Hungary and Slovakia (in Hungary the ROE fell from $55.8 \%$ to $40.2 \%$ after 2009 , the ROA decreased from $9.9 \%$ to $8 \%$ and the profit margin reduced from $5.8 \%$ to $4.1 \%$; in Slovakia the ROE steadily declined from $18.6 \%$ to $5.3 \%$ after the crisis; the ROA decreased from $10.3 \%$ to $9.8 \%$; and the profit margin declined from $9.9 \%$ to $9.6 \%$ ). The profitability ratios remained almost stable after the crisis in Poland. Regarding Czech high-tech service companies, there was no significant growth of the ROA and profit margin after the economic downturn.

It is necessary to note that the profitability and liquidity ratios of the manufacturing high-tech industry in Slovakia increased after the crisis. This could have been caused by the euro adoption in Slovakia. Another factor that brought comparable stability to Slovakia was the unlimited deposit guarantee, which gave Slovakian companies a significant competitive edge in comparison with Czech, Hungarian and Polish companies. Furthermore, the euro adoption in the Slovak economy facilitated the inflow of investments.

The financial position of the high-tech industry could have been influenced by the crisis in some circumstances. Thus, in order to analyse the economic development in the V4 countries, we consider the gross domestic growth rate. We also monitor the high-technology exports in the Visegrad countries. As we can see from figure 11 (Appendix A), the financial crisis affected the economies in the Czech Republic, Hungary and Slovakia more strongly than in Poland. The figure clearly indicates that the GDP growth was negative in the Czech Republic, Hungary and Slovakia. Only in Poland did the GDP growth stay positive in 2009. As mentioned before, the economies of the Czech Republic, Slovakia and Hungary have a strong dependence on exports, while Poland has a large internal market that proved to be quite flexible to the global financial crisis. Therefore, the decrease in demand in other countries reduced the economies in the Czech Republic, Slovakia and Hungary significantly in 2008 and 2009.

In the context of high-technology exports, the lowest value of high-tech exports in 2008 was reported in Slovakia and Poland. In 2007, the value of high-tech exports in Hungary was higher than that in the Czech Republic, but after 2010, the value of exports in the Czech Republic increased by 33\%, while the value of exports in Hungary stayed almost at the same level (figure 12, Appendix A).

Summing up, the global financial crisis affected most of the companies in the high-tech sector. The financial crisis significantly reduced the worldwide supply of investment funds. Based on European Commission data, the business enterprise expenditure on research and development decreased in the Czech Republic, Slovakia and Poland annually by $0.22-1 \%$ within the period from 2007 to 2011 . Only Hungary recorded an increase in business expenditure on R\&D by $0.84 \%$ per year (Bočková, 2013). Therefore, companies faced difficulties in finding external funds to support their investments in research and development. Long-term projects were 
cut first; thus, companies reoriented themselves in the direction of short-term projects. There is no doubt that European high-tech companies are competitive in the business-to-business markets. The countries in the Visegrad Group are known to be low-cost manufacturing-based companies. Therefore, the governments should not suspend the development of the high-tech sector. They need to use this competitive advantage to achieve further growth of such an important sector of the economy and in turn the development of the country as a whole.

In addition, we conducted a descriptive analysis of the entire high-tech industry (service and manufacture companies) (see Appendix B). The descriptive statistics show that the profitability in the hightech sector among the countries in the Visegrad Group decreased during the period from 2007 to 2011. For example, the ROE in the Czech Republic, Hungary, Poland and Slovakia declined within the investigated period. Hungary has the highest ROE (mean $=46.3$ ) among the V4 countries. Thus, the companies in Hungary operate with greater profit. The current ratio is another ratio that examines the financial strength of companies. In Slovakia, the current ratio grew within the investigated period, while in the Czech Republic and Hungary this ratio declined. However, it did not interfere in the companies in the Czech Republic to enable them to be more liquid (mean $=2.48$ ). In Poland the current ratio for the high-tech sector remained without significant change during the period from 2007 to 2011. The standard deviation values of the profitability measures were found to be higher than those of liquidity in all four countries. This indicates that the data on profitability were spread out over a large range of values. In addition, the low standard deviation of the current ratio tended to be very close to the mean. Furthermore, the mean values of the current ratio were found to vary between 1.5 and 2.7 , respectively, among the countries from the V4. These values are acceptable for a healthy business (generally considered to vary from 1.5 to 3 ). Thus, these findings are in line with the standards. The solvency ratio increased in all the analysed countries. It is greater than $20 \%$; therefore, the high-tech sector can be considered to be financially stable. In other words, companies are ready to pay their debts on time and can survive in the long term in adverse market situations.

\subsection{Two-dimensional classification of the high- tech sector}

Another part of the research is aimed to analyse the financial situation of large high-tech companies among the countries in the Visegrad Group. One of the methods used by researchers to analyse the economic and financial situation of companies is based on two-dimensional classification.

Pimental et al. (2005) classified companies according to their liquidity and profitability ratios. These two ratios are two fundamental categories of company activities (Bolek and Wilinski, 2012). Pimental et al. sorted companies by twodimensional classification based on their return on equity and current ratio. Following Pimental et al.'s classification, we identified four groups of companies to gain a picture of the economic and financial situation in the Visegrad countries. For this purpose, we selected the following ratios, which represent companies' profitability and liquidity: return on assets (ROA) and current ratio (CR). The matrix positions companies in two ways:

- the level of liquidity,

- the level of profitability.

\begin{tabular}{|c|c|c|c|}
\hline \multicolumn{2}{|c|}{} & \multicolumn{2}{c|}{ Profitability } \\
\cline { 3 - 4 } \multicolumn{2}{|c|}{} & high (h) & low (l) \\
\hline \multirow{3}{*}{ Liquidity } & High (H) & 1 & 2 \\
\cline { 2 - 4 } & Low (L) & 3 & 4 \\
\hline
\end{tabular}

Figure 13 Classification of companies according to the groups

The matrix is divided into four groups (a different type of company belongs to each group) (figure 13):

- high profitable companies - businesses that operate with profitability ratios higher than the average profitability ratios (quadrants 1 and 3);

- low profitable companies - businesses with low profitability - their profitability ratio is lower than the average (quadrants 2 and 4);

- companies with a high level of liquidity businesses with a high liquidity ratio (in our case with a current ratio higher than 1), meaning that capital is easily available and the high liquidity spurs economic growth (quadrants 1 and 2);

- companies with a low level of liquidity businesses in which the liquidity ratio is lower than 1 (quadrants 3 and 4).

Thus, this matrix allows us to determine companies' financial position. Following Pimental et al.'s (2005) classification, the companies positioned in the group with a high level of profitability and liquidity, located in quadrant 1 , are considered to be in a good financial position. The companies located in the quadrant with a low level of liquidity and a low level of profitability (quadrant 4) are considered 
to be in a poor economic and financial position. The other groups (quadrants 2 and 3) occupy the intermediate position. The results are presented in figures 14 and 15 (Appendix C).

Based on the classification, we found that in the Czech Republic and Slovakia the number of companies with a high level of profitability and a high level of liquidity remained stable during the fiveyear period, while in Hungary and Poland the number of high-tech companies with a good financial position slowly increased between 2007 and 2011. In the Czech Republic the companies with a low level of liquidity and a low level of profitability during the investigated period experienced a significant drop (from $25(18 \%)$ in 2007 to $6(4 \%)$ in 2011), while in Slovakia and Hungary this number remained fairly stable (quadrant 4 Sk2007 $=4$ companies $(11 \%)$; quadrant 4 Sk2011 = 4 companies (11\%); quadrant 4 Hu2007 = 14 companies (21\%); quadrant $4 \mathrm{Hu} 2011=13$ companies $(19 \%)$ ).

Considering the data presented in figure 14 (Appendix C), it is possible to observe that in 2011 the high-tech sector in the Czech Republic consisted of $41 \%$ of companies in the group with profitability higher than the average profitability in the industry and with high liquidity, which are considered to be in a good financial position. Another 55\% of companies were located in the group with high profit ratios and low liquidity (intermediate condition), and $4 \%$ of companies belonged to the group with low profitability and a low level of liquidity. The large high-tech companies in the Slovak Republic were distributed as follows: $30 \%$ of companies were companies with a good financial position (quadrant 1), $54 \%$ of companies were able to keep a high level of liquidity, but a low level of profitability, $5 \%$ of high-tech companies positioned themselves in quadrant (3) and the remaining $11 \%$ of companies were located in the quadrant with a low level of profitability and liquidity. The highest number of companies in the Visegrad Group with low liquidity and low profitability was found in Poland (20\%). As for Hungary, we found that $40 \%$ of companies belonged to the group with a high level of profitability and liquidity, $34 \%$ of companies had high liquidity and low profitability, another $7 \%$ were located in the group with high profitability and low liquidity and the last $19 \%$ of companies had a low level of profitability and a low level of liquidity.

To summarize, the results show that in the Czech Republic the high-tech sector consisted of 133 (96\%) companies with a high level of liquidity and $57(41 \%)$ companies belonging to the group with a high level of profitability. In Slovakia, the high-tech sector consisted of 31 (84\%) companies with a high level of liquidity and only 13 (35\%) companies with a high level of profitability. In the Hungarian hightech sector we found that there were $32(47 \%)$ companies with profitability higher than the average profitability in this industry, and $50(74 \%)$ companies had a high level of liquidity. Furthermore, in Poland there were more companies with a high level of liquidity: 208 (77\%) companies. Thus, the results indicate that in the Visegrad countries the high-tech sector consisted of companies with high liquidity, rather than companies with strong profits. This means that the companies had enough resources to pay their debts over the last business cycle.

\section{The relationship between profitability and liquidity}

In addition, in this paper we examine the relationship between liquidity and profitability. According to the literature review, there are many studies that investigate this relation. However, the dilemma concerning this relationship still exists. On the one hand, some results support the assertion that companies with larger liquidity have smaller profitability; in other words, there is a negative relationship between profitability and liquidity (Ross et al., 2000; Gitman, 2003; Eljelly, 2004; Pimental et al., 2005; Raheman and Nasr, 2007; Gajdka and Walińska, 2008). On the other hand, other researchers have argued that there is a positive relation between profitability and liquidity (Hirigoyen, 1985; Padachi, 2006; Niresh, 2012). For example, Hirigoyen (1985) stated in his study that liquidity depends on profitability and vice versa.

Therefore, to examine the relation between profitability and liquidity, we should select the universal measures of profitability and liquidity ratios. The previous studies concerning the relationship between liquidity and profitability propose to employ one ratio to represent the company profitability (Siminica et al., 2012; Sandhar and Jaglani, 2013; Afia and Khaled, 2014). However, it should be noted that some of the studies mentioned the necessity to utilize two or more measures to describe company profitability (Owolabi et al., 2011; Attari and Raza, 2012; Zygmunt, 2013). For example, Zygmunt (2013) used the return on assets and return on equity to measure profitability. Kula et al. (2012) used the ROA as a conclusive ratio. They also mentioned that this ratio expresses the performance of companies without influence on the capital structure and expresses how many currency units a company generates from each asset that it controls. The ROA is the ratio that reflects company operations in the broadest possible aspect. It reflects the effectiveness of the total operations of the company 
and has a lower amplitude of value fluctuations from general ratios of sales and equity profitability (Bolek and Wilinski, 2012). Therefore, based on the literature review, the measure chosen to represent profitability was return on assets. For the liquidity measure we considered the current ratio and liquidity ratio.

For the analysis, bivariate correlation tests were conducted to assess the relationship between the variables. The relationship between the return on assets, the current ratio and the liquidity ratio was tested using the Pearson product-moment correlation coefficient. The correlation analysis showed that in the Czech Republic there is a positive significant correlation between the variables (see Appendix $\mathrm{D}$, table 2).

Considering the data presented in table 2 (Appendix D), it is possible to observe that there is a significant correlation between the ROA and the current ratio (.219) and also between the ROA and the liquidity ratio (.217). Therefore, our findings contradict some of the previous findings that there is a negative relationship between profitability and liquidity. For Hungary and Slovakia, the correlation analysis shows that there is no significant correlation between the variables.

In terms of Poland, the relationship between profitability and liquidity was significantly correlated. This means that companies were able to reach positive income results over a certain year and they were able to keep a higher liquidity level in the following year.

Summing up, our study shows that there is a mixed relationship between profitability and liquidity in high-tech companies in the V4. Therefore, to have a clear view of this relationship, we used the linear regression method. The correlation analysis indicated that there is no significant correlation between the variables in Hungary and those in Poland. Hence, the regression analysis was conducted for the high-tech companies in the Czech Republic and Poland.

The following hypotheses were tested:

\section{Hypothesis One}

H0: There was no significant relationship between the profitability ratio and the liquidity ratio in high-tech companies in the Czech Republic in the period of five years (from 2007 to 2011).

$\mathrm{H} 1$ : There was a significant relationship between the profitability ratio and the liquidity ratio in hightech companies in the Czech Republic in the period of five years (from 2007 to 2011).

\section{Hypothesis Two}

Ho: There was no significant relationship between the profitability ratio and the liquidity ratio in high-tech companies in Poland in the period of five years (from 2007 to 2011).

$\mathrm{H} 1$ : There was a significant relationship between the profitability ratio and the liquidity ratio in hightech companies in Poland in the period of five years (from 2007 to 2011).

The statistical relationship between profitability and liquidity may be expressed as follows:

$$
Y=B_{0}+B_{1} X+\varepsilon
$$

where $Y$ is the dependent variable; $B_{1}$ represents correlation coefficient variable $Y$ in relation to variable $X ; B_{1}$ expresses the intercept; $x$ is the independent variable; and $\varepsilon$ represents the random error term.

The dependent variable represents the level of profitability in high-tech companies. The following independent measures were selected: current ratio (CR) and liquidity ratio (LR). The model summary table provides the $\mathrm{R}$ and $R^{2}$ values. The $\mathrm{R}$ square is the coefficient of determination, which tells us how the ROA varied with the changes in the current ratio and the liquidity ratio in the five-year period. The coefficients table provides us with the information to predict profitability from liquidity as well as to determine whether liquidity contributes statistically significantly to the model (by looking at the Sig. column).

In the summary table (see Appendix D) the value of $\mathrm{R}$ square is 0.048 in the Czech Republic. This implies that $4.8 \%$ of the profitability of high-tech companies was a result of the variation in the current ratio at the confidence level of $95 \%$. This means that $95.2 \%$ of the profits of high-tech companies are attributable to factors other than liquidity levels. The $\mathrm{R}$ is the correlation coefficient, which shows the nature of the relationship between the ROA and the current ratio in the long-term period. From the results above, $\mathrm{R}$ is 0.219 , which indicates a weak positive relationship between the variables.

The results indicate that the current ratio (CR, b $=.755)$ is not significant $(\mathrm{p}=.388)$. The liquidity ratio $(\mathrm{LR}, \mathrm{b}=.244, \mathrm{p}=.780)$ is also unrelated to profitability, because the p-value is more than .05 , which means that we reject hypothesis 1 . In other words, we conclude that there is no significant relationship between the profitability and the liquidity ratio in high-tech companies in the Czech Republic in the five-year period.

In the Polish high-tech sector, the multiple regression model with two predictors (CR and LR) 
produced $\mathrm{R}^{2}=.065$ and $\mathrm{R}=.254$ (Appendix $\mathrm{D}$ ). This means that $6.5 \%$ of the profits were a result of the variation in the liquidity ratios $(\mathrm{CR}, \mathrm{LR})$ at the confidence level of $95 \%$. The results from the regression analysis show that the ROA was not significantly affected by the liquidity ratio and the current ratio because the p-value was more than 0.5. Thus, we can say that there is no significant relationship between profitability and liquidity in Polish high-tech companies.

To sum up, the correlation and regression analyses were conducted to examine the relationship between profitability and liquidity. The correlation analysis was used to determine the nature and extent of the relationship between the variables, while the regression analysis was used to determine whether a cause-and-effect relationship exists between profitability and liquidity. The correlation coefficients indicated that the ROA is positively correlated in the Czech and Polish high-tech companies at the $1 \%$ level with CR and LR. The regression results indicated that neither of the two liquidity ratios, namely LQ and CR, has a significant impact on profitability in Czech and Polish high-tech companies.

\section{Conclusions}

The results of the present paper indicated that the profitability and liquidity ratios in Czech and Hungarian manufacturing high-tech companies were strongly reduced within the period from 2007 to 2011. Only in Slovakia did the manufacturing hightech companies achieve increasing profitability and liquidity within the investigated period. As for the service high-tech sector, after the crisis, the profitability declined in Hungary and Slovakia. In Poland and the Czech Republic the profitability ratios stayed without significant change after the crisis. The results also indicated that in Slovakia the profitability and liquidity ratios have increased since 2007 in manufacturing companies and the profitability ratios have decreased in service high-tech companies. Liquidity shows the strength of the high-tech sector, while profitability shows whether the business is sustainable. The profitability ratios were influenced by the economic crisis, while the liquidity and solvency ratios grew or stagnated in this period. The mean values of the current ratio were found to vary between 1.5 and 2.7 , respectively, among high-tech companies in the V4. These values are acceptable for a healthy business (generally considered to vary from 1.5 to 3 ). Thus, these findings are in line with the standards. The solvency ratio was found to be greater than $20 \%$, meaning that companies are ready to pay their debts on time and can survive in the long term in adverse market situations.

Based on the two-dimensional classification, we found that in the Visegrad countries the high-tech sector consists of companies with a high level of liquidity, rather than companies with strong profits. From the analysis, we can say that companies in the Visegrad Group hold adequate liquid assets, helping them to minimize their liquidity risks and the ramification of the crisis. Owolabi et al. (2011) mentioned that long-term growth, survival and expansion depend on profitability, while the survival of a business depends on its liquidity. Therefore, both of them are important to any company.

The research methods used to examine the nature and extent of the relationship between profitability and liquidity in high-tech companies were correlation and regression analysis. Our findings revealed that liquidity ratios (measured by the current ratio and liquidity ratio) have a weak relationship with profitability (measured by return on assets). We also found that the current ratio and liquidity ratio are not significantly associated with the return on assets. This means that liquidity has a low level of effect on the profitability of high-tech companies in the Czech Republic and Poland. This result is in line with the findings obtained by Niresh (2012) and Afia and Khaled (2014), who found a non-significant relationship between measures of liquidity and measures of profitability.

Several limitations should be mentioned with regard to our study. Firstly, only large high-tech companies were observed. Therefore, the results only refer to one industry; for that reason, it is problematic to make a general conclusion. Secondly, our study was carried out over a period of five years (from 2007 to 2011). This period may not be long enough to make a definite statement on the hightech sector in the Visegrad Group.

Additional research will be required to assess not only companies in the high-tech industry but also companies from other important sectors of the economy. Additionally, the scope of future research may be extended by examining other different indicators of organizational performance, which may reflect some new interesting relations in the mid-term and long-term period.

Despite all the above-mentioned limitations, we believe that our study will prompt researchers to conduct additional research in this area.

\section{References}

AFIA, A., KHALED, M. (2014). Liquidityprofitability relationship in Bangladesh banking 
industry. International Journal of Empirical Finance 2(4): 143-151.

ATTARI, A., RAZA, K. (2012). The optimal relationship of cash conversion cycle with firm size and profitability. International Journal of Academic Research in Business and Social Sciences 2(4): 189203.

BIMING, L. (2011). Evaluation of high-tech enterprises. Canadian Social Science 7(6): 245-248.

BOLEK, M., WILINSKI, W. (2012). The influence of liquidity on profitability of Polish construction sector companies, Financial Internet Quarterly, ,eFinanse" 8(1): 38-52.

BOČKOVÁ, N. (2013). Visegrad Four countires: evaluation in R\&D sectors of performance. Acta Universitatis Agriculturae et Silviculturae Mendelianae Brunensis 61(4): 873-880.

http://dx.doi.org/10.11118/actaun201361040873

CARTON, B., HOFER, W. (2006). Measuring organizational performance. UK: Edward Elgar Publishing.

http://dx.doi.org/10.4337/9781847202840

GAJDKA, J., WALIŃSKA, E. (2008). Zarzadzanie finansowe. Teoria i praktyk. Warszawa: Fundacja Rozwoju Rachunkowości w Polsce.

GITMAN, L. (2003). Basic Managerial Finance. New York: Harper \& Row.

GRODZICKI, M. (2014). Global value chain and competitiveness of V4 economies. Kiendl-Wendner, D. \& Wach, K. (eds). International Competitiveness in Visegrad Countries: Macro and Micro Perspectives. Graz: Fachhochschule Joanneum, 13-31.

HIRIGOYEN, G. (1985). Rentabilité et solvabilité. Direction et Gestion 3: 13-26.

NEČADOVA, M., SCHOLLEOVÁ, H. (2013). Changes in the rate of investments in the Czech and Slovak Republics and in high-tech manufacturing industry of both countries. In: Liberec Economic Forum. Liberec: Technical university of Liberec, 402-411.

NEČADOVA, M., SCHOLLEOVÁ, H. (2012). Changes in the innovation performance of the CR and development in the high-tech sector. In: The $6^{\text {th }}$ International Days of Statistics and Economics, Prague. Prague: VŠE, 13-15.

NIRESH, J. (2012). Trade-off between liquidity and profitability. International Conference Research Journal 1-11.

OWOLABI, S., OBIAKOR, R., OKWU, A. (2011). Investigating liquidity-profitability relationship in business organizations: A study of selected quoted companies in Nigeria. British Journal of Economics, Finance and Management Sciences 1(2): 12-22.

PADACHI, K (2006). Trends in working capital management and its impact on firm's performance: An analysis of Mauritian small manufacturing firm. International Review of Business Research Papers.

PIMENTAL, R., BRAGA, R., PEREIRA DE CASTRO CASA NOVA, S. (2005). Interação entre rentabilidade e liquidez: Um estudo exploratório. Revista de Contabilidade do Mestrado em Ciências Contábeis da UERJ 10(2): 83-98.

RAHEMAN, A., NASR, M. (2007). Working capital management and profitability - case of Pakistani firms. International Review of Business Research Papers 3(1): 279-300.

ROBINSON, K. (1995). Measures of Entrepreneurial Value Creation and Investigation of the Impact of Strategy and Industry Structure on the Economic Performance of Independent new Ventures. Athens: University of Georgia, GA.

ROSS, S., WESTERFIELD, R., JORDAN, B. (2000). Fundamentals of Corporate Finance. New York: McGraw-Hill.

SANDHAR, S., JANGLANI, S. (2013). A study on liquidity and profitability of selected indian cement companies: a regression modeling approach. International Journal of Economics, Commerce and Management 1(1): 1-24.

SIMINICA, D., CIRCIUMARU, D., SIMION, D. (2012). The correlation between the return on assets and the measures of financial balance for Romanian companies. International Journal of Mathematical Models and Methods in Applied Sciences 2(6): 249256.

TIMMER, M., LOS, B., STEHRER, R., DE VRIES, G. (2013). Fragmentation, incomes and jobs and analysis of European competitiveness. Economic Policy 28(76): 613-661.

http://dx.doi.org/10.1111/1468-0327.12018

ŠUSTER, M. (2006). The effects of euro adoption on the Slovak economy. BIATEC 14(6): 2-6.

\section{Additional sources}

BLOOMBERG (2013). 50 Most Innovative Countries. [online]. Available at: http://www.bloomberg. com/slideshow/2013-02-01/50-most-innovativecountries.html\#slide1.

ČESKÝ STATISCTICKÝ ÚŘAD. Available online at: http://www.czso.cz/.

EIU (Economist Intelligence Unit) (2013). [online]. Available online at http://www.eiu.com/.

KHOURY, P., HERVÉ, J. (2011). High-tech: Reevaluating Priorities and Realigning with the 
Business. [online]. Available at: http://www.capge mini.com/resources/world-quality-report--high-techsector-pull-out.

NACE (Statistical Classification of Economic Activities in the European Community) (2008). [online]. Available online at http://epp.eurostat. ec.europa.eu/statistics_explained/index.php/Glossar
y:Statistical_classification_of_economic_activities_i n_the_European_Community_(NACE).

KULA, D., BOBEK, M., ČÁMSKÁ, D., HÁJEK J. (2012). Impact of the financial crises on profitability and liquidity of companies in metallurgical industry in the Czech Republic. [online]. Available online at: http://www.metal2014.com/files/proceedings/02/rep orts/277.pdf.

\section{Appendix A}

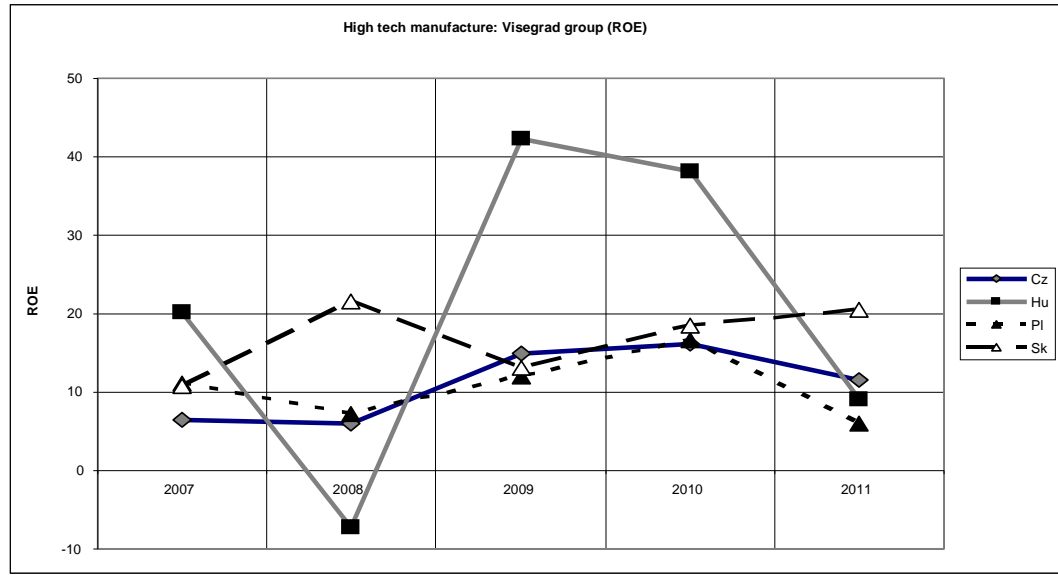

Figure 1 High tech manufacture sector: Visegrad group (ROE: 2007-2011)

Source: Own elaboration from data of Amadeus

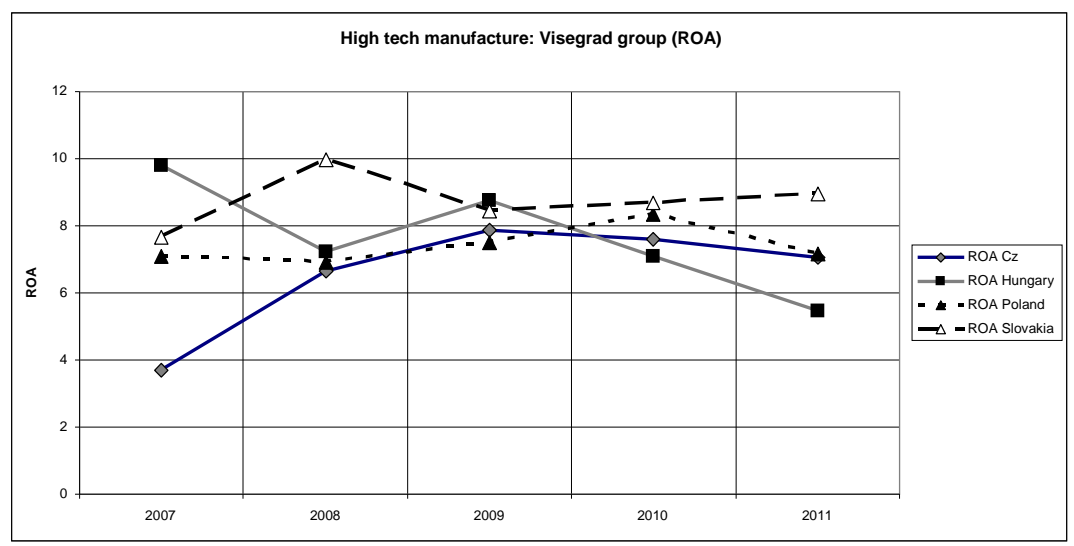

Figure 2 High tech manufacture sector: Visegrad group (ROA: 2007-2011)

Source: Own elaboration from data of Amadeus 


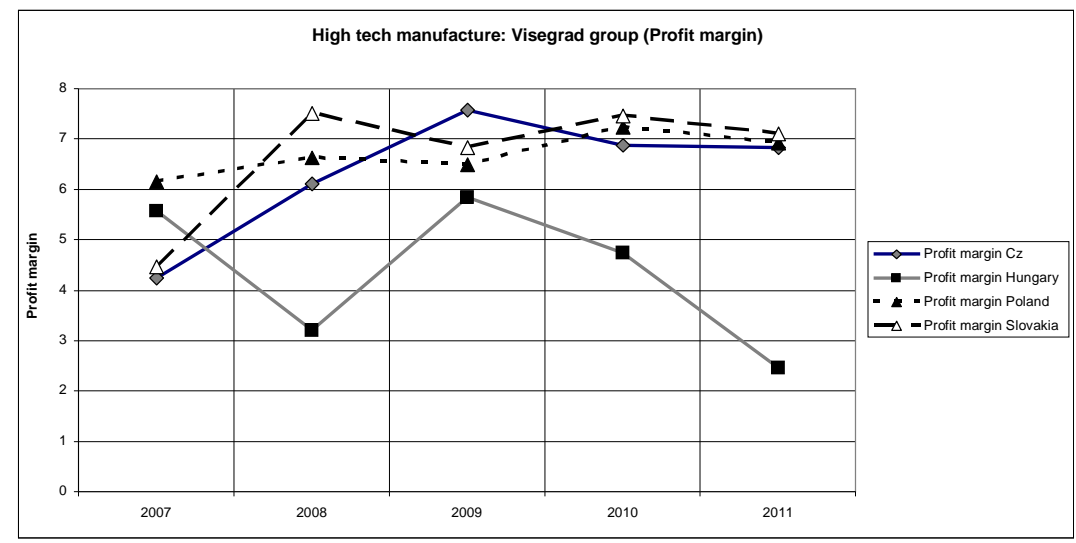

Figure 3 High tech manufacture sector: Visegrad group (Profit margin: 2007-2011) Source: Own elaboration from data of Amadeus

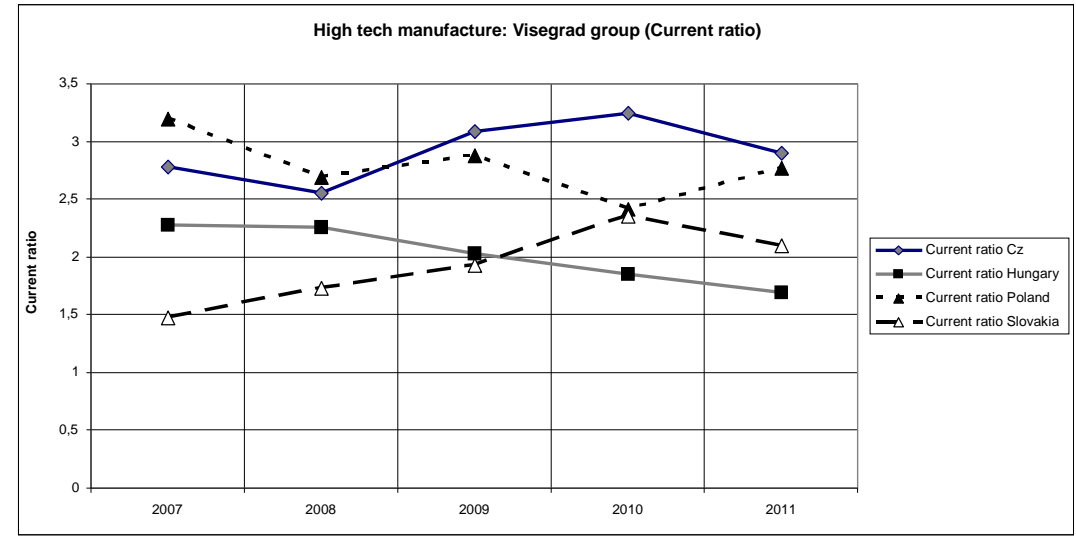

Figure 4 High tech manufacture sector: Visegrad group (Current ratio: 2007-2011)

Source: Own elaboration from data of Amadeus

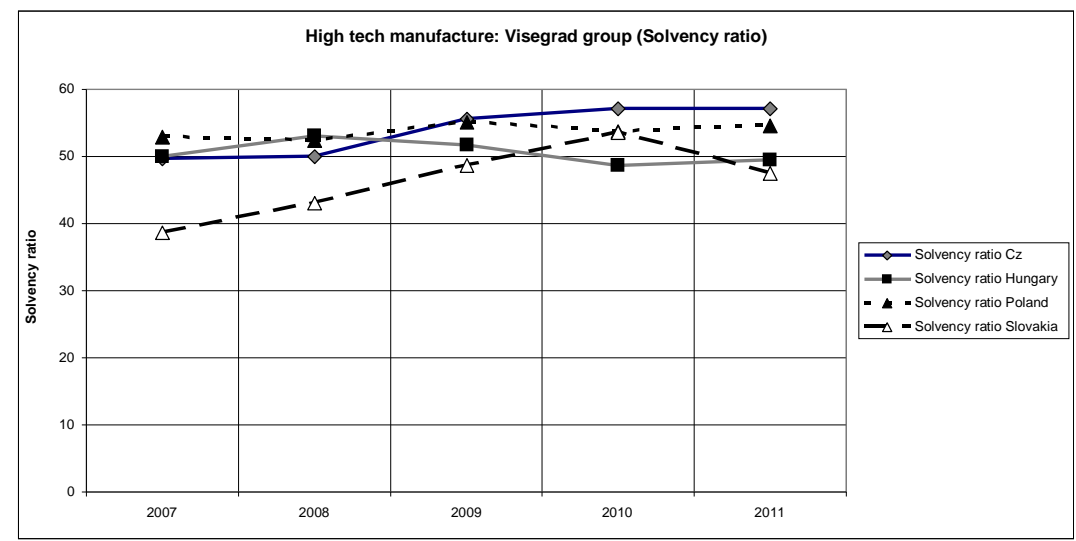

Figure 5 High tech manufacture sector: Visegrad group (Solvency ratio: 2007-2011)

Source: Own elaboration from data of Amadeus 


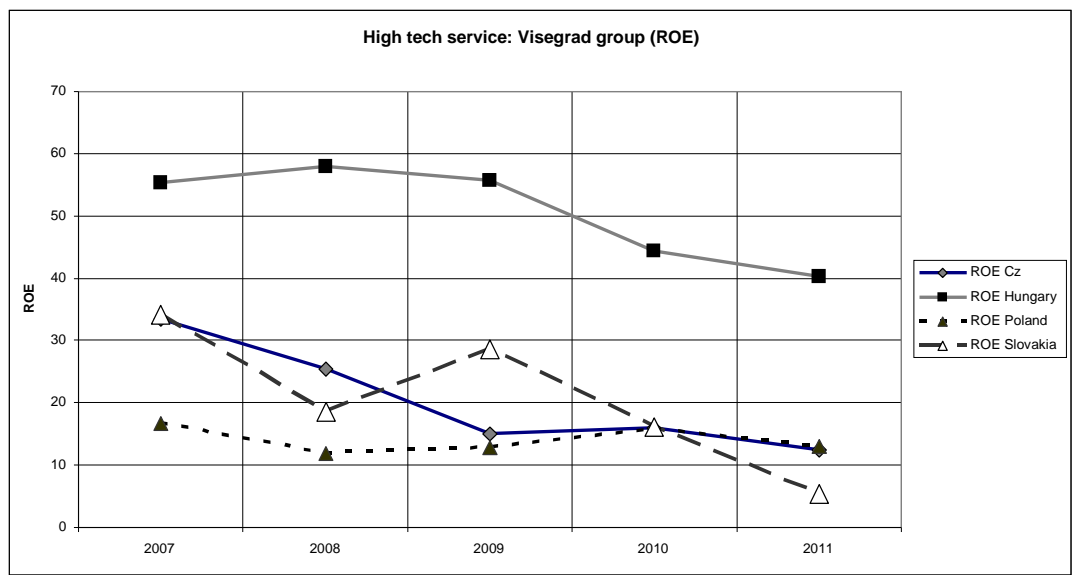

Figure 6 High tech service sector: Visegrad group (ROE: 2007-2011)

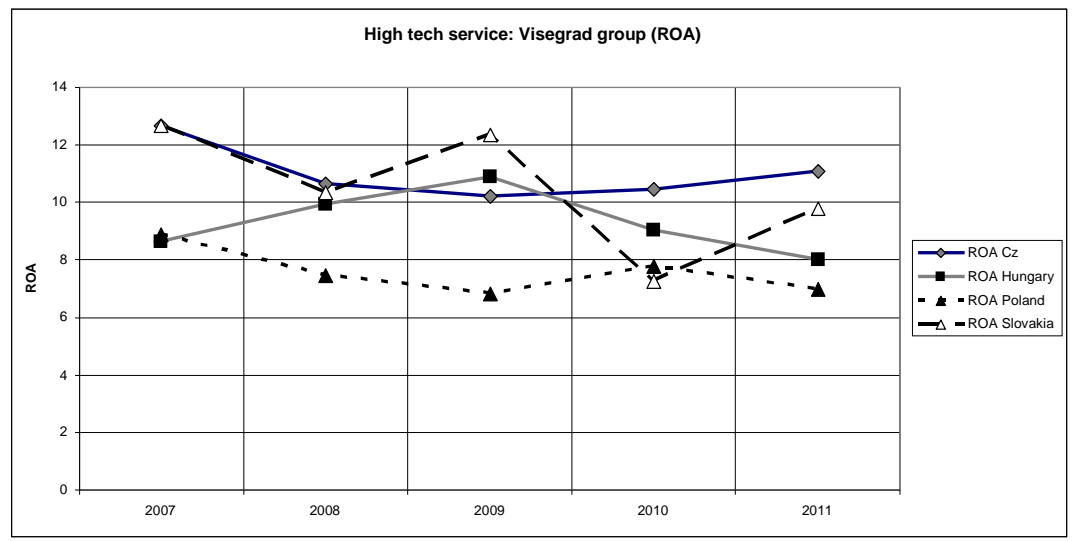

Figure 7 High tech service sector: Visegrad group (ROA: 2007-2011)

Own elaboration from data of Amadeus

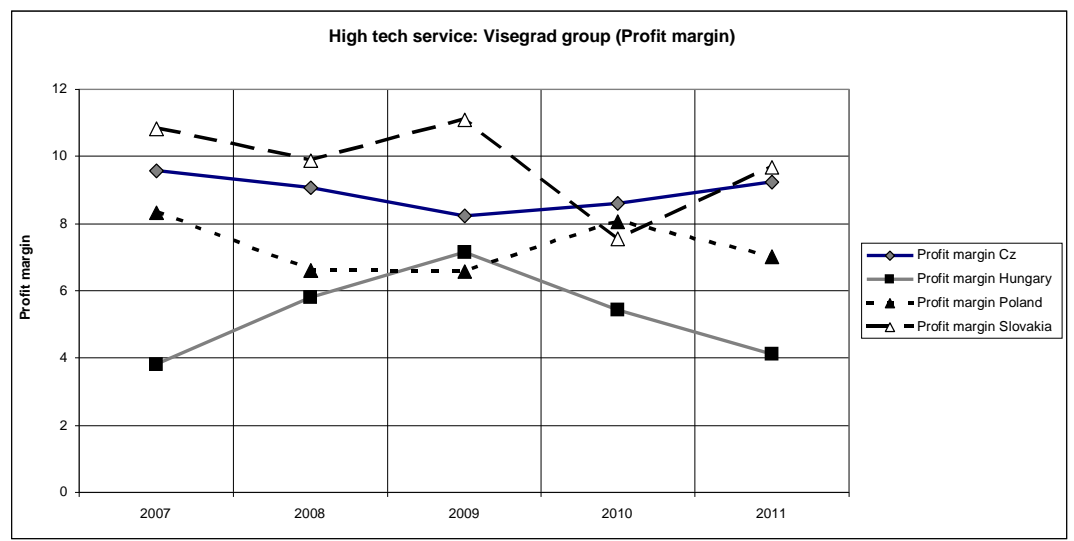

Figure 8 High tech service sector: Visegrad group (Profit margin: 2007-2011)

Source: Own elaboration from data of Amadeus 


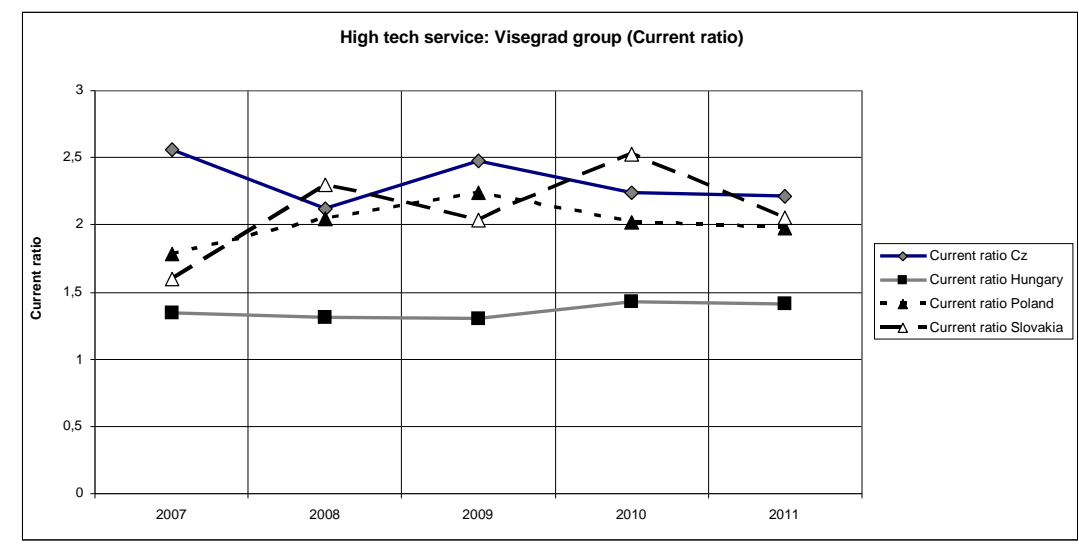

Figure 9 High tech service sector: Visegrad group (Current ratio: 2007-2011)

Source: Own elaboration from data of Amadeus

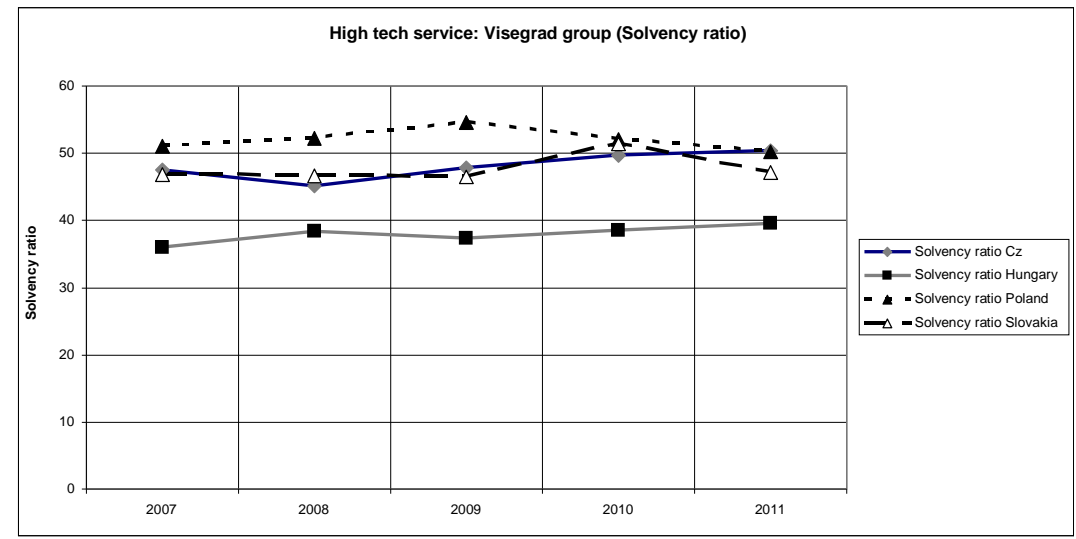

Figure 10 High tech service sector: Visegrad group (Solvency ratio: 2007-2011)

Source: Own elaboration from data of Amadeus

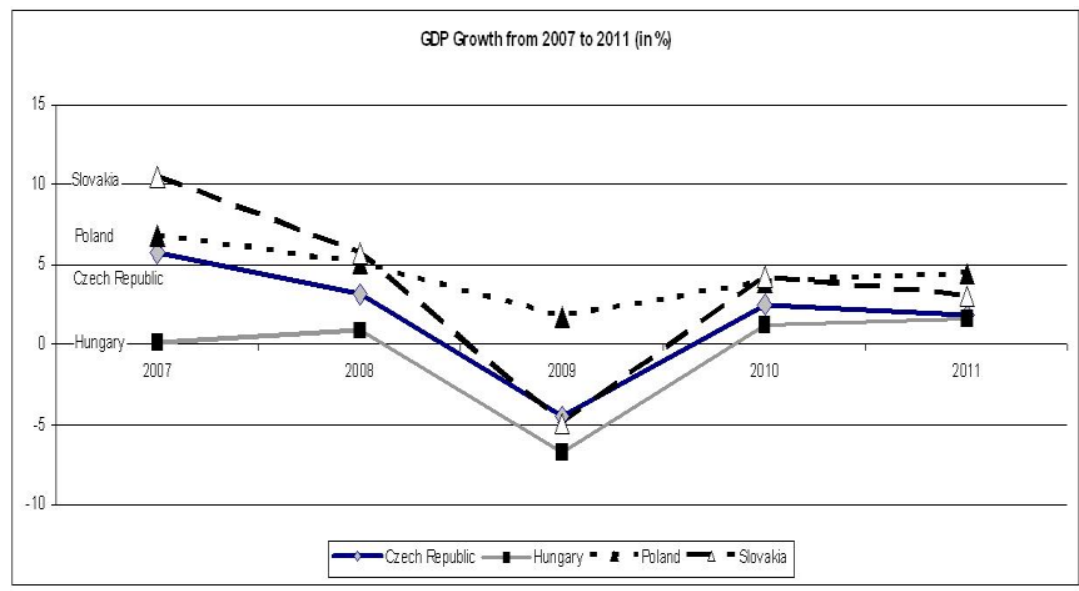

Figure 11 Gross domestic product in Visegrad group

Source: Eurostat 


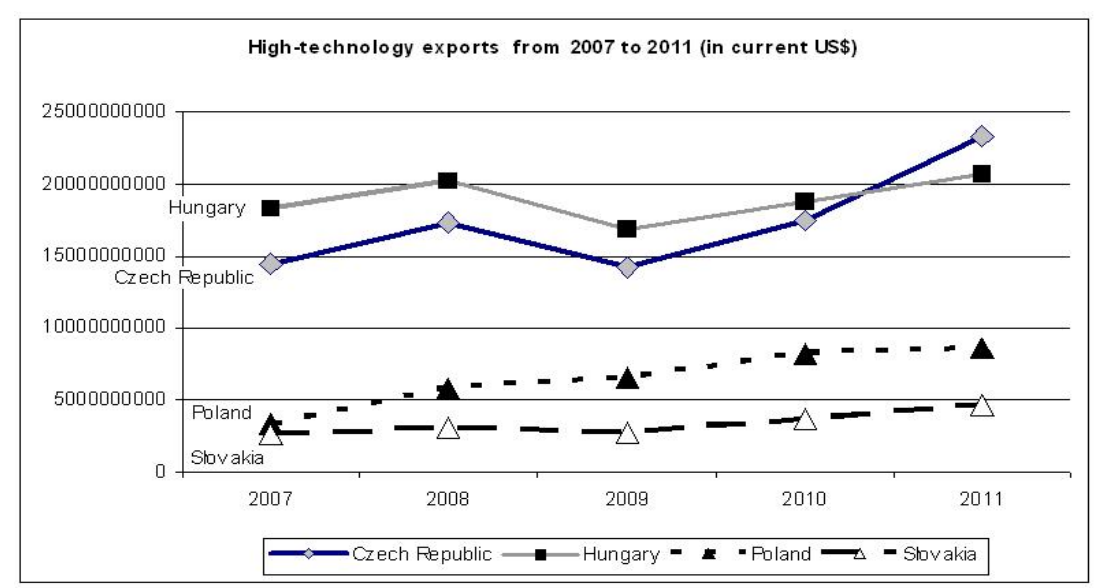

Figure 12 High-technology exports in Visegrad group Source: Eurostat

\section{Appendix B}

Descriptive statistic for period 2007-2011: large high tech companies in Czech Republic

\begin{tabular}{|l|c|c|c|c|c|c|c|c|c|c|}
\hline & \multicolumn{2}{|c}{2007} & \multicolumn{2}{c|}{2008} & \multicolumn{2}{c|}{2009} & \multicolumn{2}{c|}{2010} & \multicolumn{2}{c|}{2011} \\
\hline & Mean & Std.Deviati & Mean & Std.Deviati & Mean & Std.Deviati & Mean & Std.Deviati & Mean & Std.Deviati \\
\hline ROE & 22.95799 & 67.01169 & 17.86727 & 63.77386 & 15.03878 & 46.25323 & 16.07374 & 35.12254 & 12.09633 & 76.52027879 \\
\hline ROA & 9.117372 & 15.04523 & 9.105396 & 13.97864 & 9.309496 & 11.54348 & 9.352734 & 12.13882 & 9.522014 & 11.96988263 \\
\hline ProfitMargin & 7.464161 & 11.50869 & 7.905468 & 12.4088 & 7.963453 & 9.947218 & 7.92777 & 10.98757 & 8.299784 & 11.3589053 \\
\hline CurrentRatio & 2.648333 & 3.533406 & 2.289065 & 2.27728 & 2.714388 & 3.672609 & 2.629353 & 2.383758 & 2.481727 & 2.003894732 \\
\hline SolvencyRatio & 48.40674 & 25.12353 & 47.02043 & 24.64807 & 50.86878 & 24.88221 & 52.55667 & 23.43636 & 53.03583 & 24.27437911 \\
\hline
\end{tabular}

Descriptive statistic for period 2007-2011: large high tech companies in Hungary

\begin{tabular}{|l|c|c|c|c|c|c|c|c|c|c|}
\hline & \multicolumn{2}{|c|}{2007} & \multicolumn{2}{c|}{2008} & \multicolumn{2}{c|}{2009} & \multicolumn{2}{c|}{2010} & \multicolumn{2}{c|}{2011} \\
\hline & Mean & Std.Deviati & Mean & Std.Deviati & Mean & Std.Deviati & Mean & Std.Deviati & Mean & Std.Deviati \\
\hline ROE & 46.29242 & 115.0336 & 41.60162 & 135.6233 & 52.42868 & 102.7352 & 42.81132 & 95.97423 & 32.43353 & 110.4368779 \\
\hline ROA & 8.936765 & 12.28283 & 9.261618 & 13.58098 & 10.33574 & 12.26956 & 8.538088 & 13.62103 & 7.374265 & 13.53799643 \\
\hline ProfitMargin & 4.250588 & 13.82893 & 5.145735 & 9.18797 & 6.819265 & 9.167281 & 5.262206 & 9.734522 & 3.695147 & 11.48961224 \\
\hline CurrentRatio & 1.573088 & 1.254742 & 1.548088 & 1.177241 & 1.483676 & 1.086796 & 1.534118 & 0.99803 & 1.482353 & 0.886378036 \\
\hline SolvencyRatio & 39.49941 & 24.97558 & 41.99426 & 23.28216 & 40.89132 & 23.69785 & 41.13632 & 23.08556 & 42.03147 & 23.07456526 \\
\hline
\end{tabular}

Descriptive statistic for period 2007-2011: large high tech companies in Poland

\begin{tabular}{|l|c|c|c|c|c|c|c|c|c|c|}
\hline & \multicolumn{2}{|c}{2007} & \multicolumn{2}{c|}{2008} & \multicolumn{2}{c|}{2009} & \multicolumn{2}{c|}{2010} & \multicolumn{2}{c|}{2011} \\
\hline & Mean & Std.Deviati & Mean & Std.Deviati & Mean & Std.Deviati & Mean & Std.Deviati & Mean & Std.Deviati \\
\hline ROE & 14.81208 & 45.02728 & 10.26489 & 59.67182 & 12.58133 & 28.73543 & 16.04915 & 20.20028 & 10.51878 & 43.57219041 \\
\hline ROA & 8.251413 & 11.90819 & 7.269037 & 11.51471 & 7.057 & 11.61245 & 7.979 & 9.921738 & 7.021667 & 10.14570192 \\
\hline ProfitMargin & 7.551208 & 12.10455 & 6.618407 & 11.30478 & 6.542407 & 10.85497 & 7.761778 & 10.42146 & 6.986778 & 11.57145078 \\
\hline CurrentRatio & 2.274148 & 2.886636 & 2.272556 & 2.531467 & 2.46463 & 2.769046 & 2.158 & 1.93437 & 2.251222 & 2.297937734 \\
\hline SolvencyRatio & 51.67378 & 26.35307 & 52.25052 & 24.2366 & 54.79737 & 23.21591 & 52.66063 & 22.92904 & 51.747 & 23.50923495 \\
\hline
\end{tabular}


Descriptive statistic for period 2007-2011: large high tech companies in Slovakia

\begin{tabular}{|l|c|c|c|c|c|c|c|c|c|c|}
\hline & \multicolumn{2}{|c|}{2007} & \multicolumn{2}{c|}{2008} & \multicolumn{2}{c|}{2009} & \multicolumn{2}{c|}{2010} & \multicolumn{2}{c|}{2011} \\
\hline & Mean & Std.Deviati & Mean & Std.Deviati & Mean & Std.Deviati & Mean & Std.Deviati & Mean & Std.Deviati \\
\hline ROE & 24.69189 & 36.10558 & 19.78486 & 47.52887 & 22.28973 & 30.5104 & 17.05243 & 28.10152 & 11.42378 & 63.85250797 \\
\hline ROA & 10.61973 & 12.85134 & 10.16892 & 10.42597 & 10.75351 & 10.43012 & 7.831892 & 15.84456 & 9.445676 & 13.75666858 \\
\hline ProfitMargin & 8.169444 & 10.28032 & 8.909459 & 9.842826 & 9.368108 & 9.24147 & 7.508919 & 16.32029 & 8.634865 & 11.67411158 \\
\hline CurrentRatio & 1.546944 & 0.816298 & 2.059444 & 2.10136 & 1.993784 & 1.138382 & 2.456111 & 1.741711 & 2.071351 & 1.264122801 \\
\hline SolvencyRatio & 43.46297 & 24.49519 & 45.16541 & 22.97598 & 47.29405 & 22.71031 & 52.24568 & 22.58243 & 47.31595 & 23.07222723 \\
\hline
\end{tabular}

\section{Appendix C}

\begin{tabular}{|c|c|c|c|c|}
\hline \multicolumn{5}{|c|}{ Czech Republic } \\
\hline \multirow{2}{*}{\multicolumn{2}{|c|}{2007}} & \multicolumn{2}{|c|}{ Profitability } & \multirow[t]{2}{*}{ Total } \\
\hline & & $\mathrm{H}$ & 1 & \\
\hline \multirow{3}{*}{ liquidity } & $\mathrm{H}$ & 56 & 57 & 113 \\
\hline & $\mathrm{L}$ & 1 & 25 & 26 \\
\hline & Total & 57 & 82 & \\
\hline \multirow{2}{*}{\multicolumn{2}{|c|}{2008}} & \multicolumn{2}{|c|}{ Profitability } & Total \\
\hline & & $\mathrm{H}$ & 1 & \\
\hline \multirow{3}{*}{ Liquidity } & $\mathrm{H}$ & 47 & 65 & 112 \\
\hline & $\mathrm{L}$ & 6 & 21 & 27 \\
\hline & Total & 53 & 86 & \\
\hline \multirow{2}{*}{\multicolumn{2}{|c|}{2009}} & \multicolumn{2}{|c|}{ Profitability } & Total \\
\hline & & $\mathrm{h}$ & 1 & \\
\hline \multirow{3}{*}{ Liquidity } & $\mathrm{H}$ & 48 & 70 & 118 \\
\hline & $\mathrm{L}$ & 2 & 19 & 21 \\
\hline & Total & 50 & 89 & \\
\hline \multirow{2}{*}{\multicolumn{2}{|c|}{2010}} & \multicolumn{2}{|c|}{ Profitability } & Total \\
\hline & & $\mathrm{h}$ & 1 & \\
\hline \multirow{3}{*}{ Liquidity } & $\mathrm{H}$ & 50 & 71 & 121 \\
\hline & $\mathrm{L}$ & 5 & 13 & 18 \\
\hline & Total & 55 & 84 & \\
\hline \multirow{2}{*}{\multicolumn{2}{|c|}{2011}} & \multicolumn{2}{|c|}{ Profitability } & Total \\
\hline & & $\mathrm{h}$ & 1 & \\
\hline \multirow{3}{*}{ Liquidity } & $\mathrm{H}$ & 57 & 76 & 133 \\
\hline & $\mathrm{L}$ & 0 & 6 & 6 \\
\hline & Total & 57 & 82 & \\
\hline
\end{tabular}

\begin{tabular}{|c|c|c|c|c|}
\hline \multicolumn{5}{|c|}{ Slovakia } \\
\hline \multirow{2}{*}{\multicolumn{2}{|c|}{2007}} & \multicolumn{2}{|c|}{ Profitability } & \multirow{3}{*}{$\begin{array}{c}\text { Total } \\
27\end{array}$} \\
\hline & & \multirow{2}{*}{$\frac{\mathrm{h}}{11}$} & \multirow{2}{*}{$\frac{1}{16}$} & \\
\hline \multirow{3}{*}{ Liquidity } & $\mathrm{H}$ & & & \\
\hline & $\mathrm{L}$ & 6 & 4 & 10 \\
\hline & Total & 17 & 20 & \\
\hline \multirow{2}{*}{\multicolumn{2}{|c|}{2008}} & \multicolumn{2}{|c|}{ Profitability } & Total \\
\hline & & $\mathrm{h}$ & 1 & \\
\hline \multirow{3}{*}{ Liquidity } & $\mathrm{H}$ & 15 & 14 & 29 \\
\hline & $\mathrm{L}$ & 3 & 5 & 8 \\
\hline & Total & 18 & 19 & \\
\hline \multirow{2}{*}{\multicolumn{2}{|c|}{2009}} & \multicolumn{2}{|c|}{ Profitability } & Total \\
\hline & & $\mathrm{h}$ & 1 & \\
\hline \multirow{3}{*}{ Liquidity } & $\mathrm{H}$ & 15 & 17 & 32 \\
\hline & $\mathrm{L}$ & 1 & 4 & 5 \\
\hline & Total & 16 & 21 & \\
\hline \multirow{2}{*}{\multicolumn{2}{|c|}{2010}} & \multicolumn{2}{|c|}{ Profitability } & Total \\
\hline & & $\mathrm{h}$ & 1 & \\
\hline \multirow{3}{*}{ Liquidity } & $\mathrm{H}$ & 12 & 22 & 34 \\
\hline & $\mathrm{L}$ & 2 & 1 & 3 \\
\hline & Total & 14 & 23 & \\
\hline \multirow{2}{*}{\multicolumn{2}{|c|}{2011}} & \multicolumn{2}{|c|}{ Profitability } & Total \\
\hline & & $\mathrm{h}$ & 1 & \\
\hline \multirow{3}{*}{ Liquidity } & $\mathrm{H}$ & 11 & 20 & 31 \\
\hline & $\mathrm{L}$ & 2 & 4 & 6 \\
\hline & Total & 13 & 24 & \\
\hline
\end{tabular}

Figure 14 Classification of companies according to the groups: Czech Republic and Slovakia (2007-2011) 


\begin{tabular}{|c|c|c|c|c|}
\hline \multicolumn{5}{|c|}{ Hungary } \\
\hline \multirow{2}{*}{\multicolumn{2}{|c|}{2007}} & \multicolumn{2}{|c|}{ Profitability } & \multirow[t]{2}{*}{ Total } \\
\hline & & $\mathrm{H}$ & 1 & \\
\hline \multirow{2}{*}{ Liquidity } & $\mathrm{H}$ & 19 & 26 & 45 \\
\hline & $\mathrm{L}$ & 9 & 14 & 23 \\
\hline & Total & 28 & 40 & \\
\hline \multirow{2}{*}{\multicolumn{2}{|c|}{2008}} & \multicolumn{2}{|c|}{ Profitability } & Total \\
\hline & & $\mathrm{H}$ & 1 & \\
\hline \multirow{2}{*}{ Liquidity } & $\mathrm{H}$ & 26 & 21 & 47 \\
\hline & $\mathrm{L}$ & 5 & 16 & 21 \\
\hline & Total & 31 & 37 & \\
\hline \multirow{2}{*}{\multicolumn{2}{|c|}{2009}} & \multicolumn{2}{|c|}{ Profitability } & Total \\
\hline & & $\mathrm{H}$ & 1 & \\
\hline \multirow{2}{*}{ Liquidity } & $\mathrm{H}$ & 22 & 27 & 49 \\
\hline & $\mathrm{L}$ & 6 & 13 & 19 \\
\hline & Total & 28 & 40 & \\
\hline \multirow{2}{*}{\multicolumn{2}{|c|}{2010}} & \multicolumn{2}{|c|}{ Profitability } & Total \\
\hline & & $\mathrm{H}$ & 1 & \\
\hline \multirow{2}{*}{ Liquidity } & $\mathrm{H}$ & 27 & 22 & 49 \\
\hline & $\mathrm{L}$ & 3 & 16 & 19 \\
\hline & Total & 30 & 38 & \\
\hline \multirow{2}{*}{\multicolumn{2}{|c|}{2011}} & \multicolumn{2}{|c|}{ Profitability } & Total \\
\hline & & $\mathrm{H}$ & 1 & \\
\hline \multirow{3}{*}{ Liquidity } & $\mathrm{H}$ & 27 & 23 & 50 \\
\hline & $\mathrm{L}$ & 5 & 13 & 18 \\
\hline & Total & 32 & 36 & \\
\hline
\end{tabular}

\begin{tabular}{|c|c|c|c|c|}
\hline \multicolumn{5}{|c|}{ Poland } \\
\hline \multirow{2}{*}{\multicolumn{2}{|c|}{2007}} & \multicolumn{2}{|c|}{ Profitability } & \multirow{3}{*}{$\begin{array}{l}\text { Total } \\
211\end{array}$} \\
\hline & & $\mathrm{h}$ & 1 & \\
\hline \multirow{3}{*}{ Liquidity } & $\mathrm{H}$ & 95 & 116 & \\
\hline & $\mathrm{L}$ & 9 & 50 & 59 \\
\hline & Total & 104 & 166 & \\
\hline \multirow{2}{*}{\multicolumn{2}{|c|}{2008}} & \multicolumn{2}{|c|}{ Profitability } & Total \\
\hline & & $\mathrm{h}$ & 1 & \\
\hline \multirow{3}{*}{ Liquidity } & $\mathrm{H}$ & 100 & 108 & 208 \\
\hline & $\mathrm{L}$ & 5 & 57 & 62 \\
\hline & Total & 105 & 165 & \\
\hline \multirow{2}{*}{\multicolumn{2}{|c|}{2009}} & \multicolumn{2}{|c|}{ Profitability } & Total \\
\hline & & $\mathrm{h}$ & 1 & \\
\hline \multirow{3}{*}{ Liquidity } & $\mathrm{H}$ & 102 & 107 & 209 \\
\hline & $\mathrm{L}$ & 6 & 55 & 61 \\
\hline & Total & 108 & 162 & \\
\hline \multirow{2}{*}{\multicolumn{2}{|c|}{2010}} & \multicolumn{2}{|c|}{ Profitability } & Total \\
\hline & & $\mathrm{h}$ & 1 & \\
\hline \multirow{3}{*}{ Liquidity } & $\mathrm{H}$ & 96 & 109 & 205 \\
\hline & $\mathrm{L}$ & 4 & 61 & 65 \\
\hline & Total & 100 & 170 & \\
\hline \multirow{2}{*}{\multicolumn{2}{|c|}{2011}} & \multicolumn{2}{|c|}{ Profitability } & Total \\
\hline & & $\mathrm{h}$ & 1 & \\
\hline \multirow{3}{*}{ Liquidity } & $\mathrm{H}$ & 104 & 104 & 208 \\
\hline & $\mathrm{L}$ & 8 & 54 & 62 \\
\hline & Total & 112 & 158 & \\
\hline
\end{tabular}

Figure 15 Classification of companies according to the groups: Hungary and Poland (2007-2011). Source: Own elaboration. 


\section{Appendix D}

Table 2 Correlation between profitability and liquidity ratios in Czech Republic (2007-2011)

\begin{tabular}{|l|l|c|c|c|}
\hline \multicolumn{2}{|c|}{} & ROA & CR & LR \\
\hline \multirow{2}{*}{ ROA } & $\begin{array}{l}\text { Pearson } \\
\text { Correlation }\end{array}$ & 1 & $.219(* *)$ & $.217(* *)$ \\
\cline { 2 - 5 } & Sig. (2-tailed) & & .000 & .000 \\
\hline CR & $\begin{array}{l}\text { Pearson } \\
\text { Correlation }\end{array}$ & $.219(* *)$ & 1 & $.981(* *)$ \\
\cline { 2 - 5 } & Sig. (2-tailed) & .000 & & .000 \\
\hline \multirow{2}{*}{ LR } & $\begin{array}{l}\text { Pearson } \\
\text { Correlation }\end{array}$ & $.217(* *)$ & $.981(* *)$ & 1 \\
\cline { 2 - 5 } & Sig. (2-tailed) & .000 & .000 & \\
\hline
\end{tabular}

** Correlation is significant at the 0.01 level (2-tailed).

Table 3 Correlation between profitability and liquidity ratios in Hungary (2007-2011)

\begin{tabular}{|l|l|c|c|c|}
\hline \multicolumn{2}{|c|}{} & ROA & CR & LR \\
\hline \multirow{2}{*}{ ROA } & $\begin{array}{l}\text { Pearson } \\
\text { Correlation }\end{array}$ & 1 & .080 & .010 \\
\cline { 2 - 5 } & Sig. (2-tailed) & & .140 & .935 \\
\hline \multirow{2}{*}{ CR } & $\begin{array}{l}\text { Pearson } \\
\text { Correlation }\end{array}$ & .080 & 1 & $.255\left(^{*}\right)$ \\
\cline { 2 - 5 } & Sig. (2-tailed) & .140 & & .036 \\
\hline & $\begin{array}{l}\text { Pearson } \\
\text { Correlation }\end{array}$ & .010 & $.255\left(^{*}\right)$ & 1 \\
\cline { 2 - 5 } & Sig. (2-tailed) & .935 & .036 & \\
\hline
\end{tabular}

* Correlation is significant at the 0.05 level (2-tailed).

\begin{tabular}{|c|c|c|c|c|}
\hline \multicolumn{2}{|c|}{$\begin{array}{l}\text { Table } 4 \text { Correlation bet } \\
\text { ratios in Slovakia (2007-2 }\end{array}$} & ROA & $\mathrm{CR}$ & LR \\
\hline \multirow[t]{2}{*}{ ROA } & $\begin{array}{l}\text { Pearson } \\
\text { Correlation }\end{array}$ & 1 & .037 & .401 \\
\hline & Sig. (2-tailed) & & .619 & .114 \\
\hline \multirow[t]{2}{*}{$\mathrm{CR}$} & $\begin{array}{l}\text { Pearson } \\
\text { Correlation }\end{array}$ & .037 & 1 & .238 \\
\hline & Sig. (2-tailed) & .619 & & .163 \\
\hline \multirow[t]{2}{*}{ LR } & $\begin{array}{l}\text { Pearson } \\
\text { Correlation }\end{array}$ & .401 & .238 & 1 \\
\hline & Sig. (2-tailed) & .114 & .163 & \\
\hline
\end{tabular}

* Correlation is significant at the 0.05 level (2-tailed).

Table 5 Correlation between profitability and liquidity ratios in Poland (2007-2011)

\begin{tabular}{|l|l|c|c|c|}
\hline \multicolumn{2}{|c|}{} & ROA & CR & LR \\
\hline \multirow{2}{*}{ ROA } & $\begin{array}{l}\text { Pearson } \\
\text { Correlation }\end{array}$ & 1 & $.076(* *)$ & $.205(* *)$ \\
\cline { 2 - 5 } & Sig. (2-tailed) & & .005 & .001 \\
\hline CR & $\begin{array}{l}\text { Pearson } \\
\text { Correlation }\end{array}$ & $.076(* *)$ & 1 & $.798(* *)$ \\
\cline { 2 - 5 } & Sig. (2-tailed) & .005 & & .000 \\
\hline \multirow{2}{*}{ LR } & $\begin{array}{l}\text { Pearson } \\
\text { Correlation }\end{array}$ & $.205(* *)$ & $.798(* *)$ & 1 \\
\cline { 2 - 5 } & Sig. (2-tailed) & .001 & .000 & \\
\hline
\end{tabular}

** Correlation is significant at the 0.01 level (2-tailed)

Czech Republic

Model Summary

\begin{tabular}{|l|c|c|c|c|}
\hline Model & $\mathrm{R}$ & R Square & Adjusted R Square & Std. Error of the Estimate \\
\hline 1 & $.219(\mathrm{a})$ & .048 & .045 & 12.66478 \\
\hline
\end{tabular}

a Predictors: (Constant), LR, CR

Coefficients $^{\text {a }}$

\begin{tabular}{|c|c|c|c|c|c|}
\hline \multirow{2}{*}{ Model } & \multicolumn{2}{|c|}{ Unstandardized Coefficients } & Standardized Coefficients & \multirow{2}{*}{$\mathrm{t}$} & \multirow{2}{*}{ Sig. } \\
\cline { 2 - 6 } & $\mathrm{B}$ & Std. Error & Beta & & \\
\hline 1 (Constant) & 6.732 & .647 & & 10.406 & .000 \\
\hline CR & .755 & .873 & .166 & .864 & .388 \\
\hline LR & .244 & .874 & .054 & .279 & .780 \\
\hline
\end{tabular}

a Dependent Variable: ROA

Poland

Model Summary

\begin{tabular}{|l|c|c|c|c|}
\hline Model & $\mathrm{R}$ & $\mathrm{R}$ Square & Adjusted R Square & Std. Error of the Estimate \\
\hline 1 & $.254(\mathrm{a})$ & .065 & .058 & 11.53880 \\
\hline
\end{tabular}

a Predictors: (Constant), LR, CR

Coefficients $^{\text {a }}$

\begin{tabular}{|c|c|c|c|c|c|}
\hline \multirow{2}{*}{ Model } & \multicolumn{2}{|c|}{ Unstandardized Coefficients } & Standardized Coefficients & \multirow{2}{*}{$\mathrm{t}$} & \multirow{2}{*}{ Sig. } \\
\cline { 2 - 6 } & $\mathrm{B}$ & Std. Error & Beta & & \\
\hline 1 (Constant) & 5.859 & .953 & & 6.151 & .000 \\
\hline CR & 1.029 & .404 & .250 & 2.547 & .323 \\
\hline L & .025 & .466 & .005 & .054 & .957 \\
\hline
\end{tabular}

\footnotetext{
${ }^{a}$ Dependent Variable: ROA
} 
